\title{
KARAKTERISTIK DINAMIK COMPUTER NUMERICAL CONTROL MILLING ROUTER 4 AXIS
}

\author{
Mochamad Saidiman ${ }^{1}$, Muhammad Satya Nugroho ${ }^{2}$, Subekti $^{3}$, Abdul Hammid ${ }^{4}$ \\ Program Studi Teknik Industri ${ }^{1}$, Program Studi Teknik Mesin ${ }^{2,3,4}$ \\ Sekolah Tinggi Teknologi Bandung ${ }^{1}$, Universitas Mercu Buana ${ }^{2,3,4}$ \\ aturihza@yahoo.com ${ }^{1,2,3,4}$
}

\begin{abstract}
Abstrak
Penelitian ini dilakukan untuk mengetahui karakteristik dinamik Computer Numerical Control Router 4 Axis dengan menggunakan metode Bump Test. Pengujian dilakukan dengan cara menempatkan sensor Accelerometer Khoctek 107b pada Mesin CNC Router 4 Axis pada sumbu $\mathrm{x}, \mathrm{y}, \mathrm{z}$ dikerangka atas, kerangka bawah, dan spindle. Hasil eksperimen pengujian getaran Mesin CNC dibagi kedalam dua proses pengujian yaitu kondisi normal dan kondisi rusak pada masing-masing sumbu. Diperoleh bahwa pengujian ini menghasilkan frekuensi global dimana frekuensi $8 \mathrm{~Hz}, 24 \mathrm{~Hz}$, dan $40 \mathrm{~Hz}$ muncul disetiap sumbu x, y, dan z pada kerangka atas, kerangka bawah dan spindle. Pada mesin dengan kondisi rusak muncul frekuensi lokal pada sumbu y kerangka atas sebesar $5 \mathrm{~Hz}$. Kemudian pada sumbu y spindle muncul frekuensi lokal sebesar $10 \mathrm{~Hz}, 56 \mathrm{~Hz}$, dan $88 \mathrm{~Hz}$. Munculnya frekuensi lokal menandakan adanya kerusakan pada CNC oleh sumbu tertentu selain frekuensi global.
\end{abstract}

Kata kunci : Karakteristik Dinamik, CNC, Bump Test, Frekuensi Lokal dan Global.

\begin{abstract}
This research was conducted to determine the dynamic characteristics of the 4 Axis Computer Numerical Control Router using the Bump Test method. The test was carried out by placing the Khoctek $107 \mathrm{~b}$ Accelerometer sensor on the 4 Axis CNC Router Machine on the $x, y, z$ axes in the upper frame, lower frame, and spindle. The experimental results of CNC machine vibration testing are divided into two test processes, namely normal conditions and damaged conditions on each axis. It was found that this test produces a global frequency where the frequencies of $8 \mathrm{~Hz}, 24 \mathrm{~Hz}$, and $40 \mathrm{~Hz}$ appear in each $x, y$, and zaxis in the upper frame, lower frame and spindle. On a machine with a faulty condition, a local frequency on the y-axis of the upper frame appears at $5 \mathrm{~Hz}$. Then on the y-axis of the spindle appear local frequencies of $10 \mathrm{~Hz}, 56 \mathrm{~Hz}$, and $88 \mathrm{~Hz}$. The appearance of a local frequency indicates a malfunction of the CNC by a certain axis other than the global frequency.
\end{abstract}

Keywords : Dynamic Characteristics, CNC, Bump Test, Local And Global Frequency

\section{PENDAHULUAN}

Penggunaan mesin berteknologi Computer Numerical Control (CNC) semakin berkembang. Pada umumnya manusia masih menggunakan keahlian tangan untuk membuat suatu design atau model tertentu, oleh karena itu kemunculan mesin $\mathrm{CNC}$ menjadikan pekerjaan yang rumit serta membutuhkan waktu yang lama dalam pengerjaannya dapat terselesaikan dengan lebih cepat dan lebih mudah. Produk-produk yang dihasilkan mesin CNC memiliki tingkat kepresisian yang tinggi.

Penggunaan mesin CNC dapat dijumpai pada industri skala besar sampai skala menengah. CNC turning, milling, grinding dan lainnya memiliki fungsi yang dapat membuat komponen yang dapat diproduksi berkali-kali dengan akurasi dan presisi yang tepat [1]. Produk yang dihasilkan oleh mesin CNC diperintahkan lewat suatu program yang biasa disebut $\mathrm{G}$ code yang terdapat dalam komputer. Program ini terdapat serangkaian kode intruksi dalam bentuk numerik (Numerical Code). NC yang didesain dari produk yang akan dibuat beserta urutan proses permesinannya. Komputer merupakan sebagai kontrol terhadap mesin CNC.

Getaran pada suatu benda kerja dan pahat merupakan variabel terikat yang mana getaran dapat selalu terjadi selama proses pemesinan berlangsung, Efek di saat dari getaran pemesinan yang terjadi pada mesin milling sangat berpengaruh pada hasil proses milling CNC seperti pada bagian kekasaran permukaan. Pada kerangka mesin CNC dapat terjadi getaran yang berlebih akibat terjadi kerusakan, Karena itu pada pembahasan karya tulis ini mengambil judul " Karakteristik Dinamik Computer Numerical Control Milling Router 4 Axis " dengan metode pengujian getaran. Metode ini digunakan untuk memberikan gambaran pengujian, mengetahui kondisi optimal dari parameter permesinan terhadap getaran dengan metode fungsi respon frekuensi (FRF) yang dilihat pada sumbu x, sumbu y, sumbu z.

Pada penelitian ini akan dilakukan pengujian terhadap Mesin CNC Router 4 Axis yang telah dirakit, yaitu difokuskan pada pengujian besarnya getaran yang timbul pada Mesin CNC Router 4 Axis dengan menggunakan metode Bump Test menggunakan analisis fungsi respons frekeunsi (FRF). Penelitian mengenai FRF telah banyak dilakukan, seperti untuk mengetahui karakteristik dinamik pada mesin diesel [2] sedangan pada sistem power train[3], needle bearing pada camshaft dohc suzuki satria fu150 yang telah di modifikasi, dengan metode bump test[4] dan Disc Brake [5,6]. Selain itu, metoda FRF dapat mengetahui adanya keausan pada disc brake daihatsu sigra[7]. Menganalisis kerusakan tapper bearing dengan menggunakan metoda FRF[8] dan karakteristik getaran yang dimiliki oleh tappered roller bearing [9] serta ball bearing [10] sebelum dan sesudah pelumasan (oli \& grease). Metoda FRF dilakukan untuk mengetahui adanya kerusakan pada sebuah stuktur [11]. Pengujian mesin Mesin CNC Router 4 Axis akibat kerusakan insert dengan metoda getaran [12]. Anlisis getaran 
dapat mempredeksi kerusakan pada screw compressor [13]. Selain itu, Ekstraksi Parameter Statistik Domain Waktu Dan Domain Frekuensi Untuk Mendeteksi Kavitasi Pada Pompa Sentrifugal Berbasis Principal Component Analysis (PCA) [14].

\section{TINJAUAN PUSTAKA}

Fungsi Respon Frekuensi (FRF) merupakan perbandingan antara sinyal respon getaran yang diterima oleh suatu struktur mekanika akibat adanya gaya eksitasi getaran dari suatu sistem dalam domain frekuensi. Sinyal respons getaran maupun sinyal eksitasi getaran keduanya diukur secara bersaman dengan mengunakan sensor getaran yang merupakan alat ukur gaya exsitasi. Dengan menggunakan transformasi Fourier, data hasil pengukuran tersebut oleh dan hasil transformasi diperoleh dalam domain frekuensi. Suatu sistem yang ditunjukkan pada Gambar 1 menunjukkan suatu sistem massa, pegas dan peredam. Sistem ini dikenakan sebuah gaya sebesar Fo secara terus menerus. Sistem tersebut sering disebut sebagai single degree of freedom (SDOF).

Pada sistem SDOF dapat diketahui frekuensi pribadi sistem, frekuensi pribadi adalah frekuensi dimana suatu sistem struktur yang memiliki massa dan kekakuan berosilasi, ketika diberikan gaya eksitasi, apabila gaya tersebut dihilangkan maka struktur tersebut akan bersosilasi secara bebas. Frekuensi pribadi merupakan bagian dari modal property. Bentuk dari perpindahan struktur tersebut ketika bergetar disebut dengan modus getar. Frekuensi getar sangat dipengaruhi oleh properti fisik dari struktur tersebut.

Apabila ingin diketahui amplitude simpangan x yang terjadi, maka perlu diketahui karakteristik besarnya x terhadap $\omega$. Dari diagram benda bebas pada Gambar 1, persamaan gerak benda tersebut adalah [15] :

\section{Misalkan :}

$$
m \ddot{x}+c \dot{x}+k x=F_{o}
$$

$$
\begin{aligned}
x & =X e^{i \omega t} \\
\dot{x} & =i \omega X e^{i \omega t} \\
\ddot{x} & =-\omega^{2} X e^{i \omega t} \\
F_{o} & =F e^{i \omega t}
\end{aligned}
$$

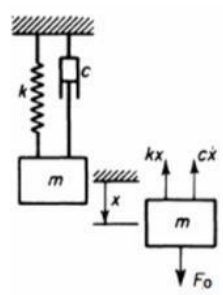

Gambar 1. Model Sistem Getaran SDOF

Subsitusikan persamaan (2) sampai (5) ke persamaan (1) sehingga diperoleh :

$$
\begin{gathered}
-m \omega^{2} X e^{i \omega t}+c i \omega X e^{i \omega t}+k X e^{i \omega t}=F e^{i \omega t} \\
\left\{\left(k-m \omega^{2}\right)+i(c \omega)\right\} X e^{i \omega t}=F e^{i \omega t} \\
\frac{X}{F}=\frac{1}{\left(k-m \omega^{2}\right)+i(c \omega)} \\
=\frac{1}{k\left[1-\left(\frac{\omega}{\omega_{n}}\right)^{2}+i 2 \zeta\left(\frac{\omega}{\omega_{n}}\right)\right]}
\end{gathered}
$$

Dari persamaan (9) maka dapat diperoleh persamaan magnitude dan sudut fase sebagai berikut :

$$
\begin{array}{r}
|H(\omega)|=\frac{1}{\left(k-m \omega^{2}\right)+i(c \omega)} \\
=\frac{1}{k\left[\left(1-\left(\frac{\omega}{\omega_{n}}\right)^{2}\right)^{2}+\left(2 z\left(\frac{\omega}{\omega_{n}}\right)\right)^{2}\right]}
\end{array}
$$

Sedangkan sudut fase adalah :

$$
\begin{aligned}
\varphi & =\tan ^{-1}\left(\frac{c \omega}{k-m \omega^{2}}\right) \\
& =\tan ^{-1}\left(\frac{2 \zeta\left(\frac{\omega}{\omega_{n}}\right)}{1-\left(\frac{\omega}{\omega_{n}}\right)^{2}}\right)
\end{aligned}
$$


FRF dapat diperoleh dengan mengukur spekturm frekuensi dari sinyal respon getaran yang diterima oleh suatu struktur mekanika akibat adanya gaya eksitasi getaran. Fungsi response ferkuensi dibagi kedalam tiga kelompok berdasarkan respon yang diukur, yaitu :

1. Responnya berupa perpindahan, disebut Receptance:

$$
\alpha(\omega)=\frac{X}{F}
$$

2. Responnya berupa kecepatan, disebut Mobility:

$$
Y(\omega)=\omega \alpha(\omega)
$$

3. Responnya berupa percepatan, disebut Inertance :

$$
A(\omega)=-\omega^{2} \alpha(\omega)
$$

Pada pengukuran getaran RC sinyal hasil pengukuran diperoleh dari response sinyal yang berasal dari dalam atau diluar dari RC tersebut. Pada umumnya untuk mengetahui sinyal dari sumber getaran biasanya diukur dalam domain waktu, hal ini untuk menggambarkan bentuk asli dari sinyal getaran pada struktur yang diukur. Sinyal sederhana dalam domain waktu sangat mudah untuk dianalisis akan tetapi pada sinyal komplek tentu akan sulit untuk dilakukan analisis. Sehingga memerlukan analisis dalam domain frekuensi, domain frekuensi diperoleh dengan menggunakan FFT, dimana setiap sinyal periodic merupakan hasil dari penjumlahan dari sinyal sinus atau kosinus yang terdapat frekunesi yang berbeda- beda.

Sebagai contoh perhitungan Nilai Konstanta, Rasio Redaman, dan Nilai Demping, misalkan diperoleh frekuensi pribadi seperti berikut :

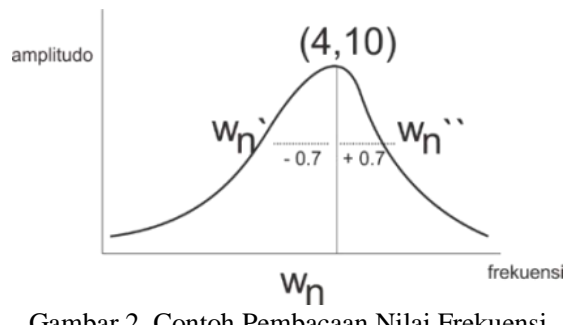

Gambar 2. Contoh Pembacaan Nilai Frekuensi

Untuk mencari nilai konstanta $(\mathrm{k})$ secara matematik yang diketahui dari hasil eksperimen dilakukan perhitungan konstanta terlebih dahulu dengan cara sebagai berikut :

Diketahui $\omega_{n}=4 \mathrm{~Hz}$

Maka nilai $\mathrm{k}$ :

$$
k=\omega_{n}^{2} \cdot m
$$

Dengan $\mathrm{m}$ adalah massa mesin $\mathrm{CNC}, \mathrm{m}=80 \mathrm{~kg}$, maka:

$$
\square=4^{2} \cdot 80=1280 \square / \square
$$

Untuk mencari rasio redaman $q$ :

$$
\begin{aligned}
& \omega^{\prime}-\omega^{\prime \prime} \\
& q=n \overline{\omega n}^{n}
\end{aligned}
$$

Maka nilai q yaitu :

$$
q=\frac{4.7-3.3}{4}=0.35
$$

Untuk mencari nilai dumping c, diketahui persamaan dari $q$ :

$$
q=\frac{c}{c c}
$$

Dengan $c c$ adalah ratio dumping

$$
\begin{aligned}
& c c=2 \cdot \sqrt{k \cdot m} \\
& \text { Maka } c \text { adalah: } \\
& c=q \cdot c c \\
& c=q \cdot 2 \cdot \sqrt{k \cdot m}
\end{aligned}
$$

Sehingga $c$ dapat dihitung

$$
c=0.35 \cdot 2 \cdot \sqrt{1280 \cdot 80}=224 \mathrm{~N} . \mathrm{sec} / \mathrm{cm}
$$




\section{METODOLOGI}

Pelaksanaan pengujian ini dapat dibagi dalam beberapa tahap agar proses analisa yang dilakukan dapat berjalan dengan baik untuk mencari getaran pada mesin. Secara umum tahapannya adalah persiapan mesin dan alat uji, pengambilan data. Dengan penjelasan sebagai berikut :
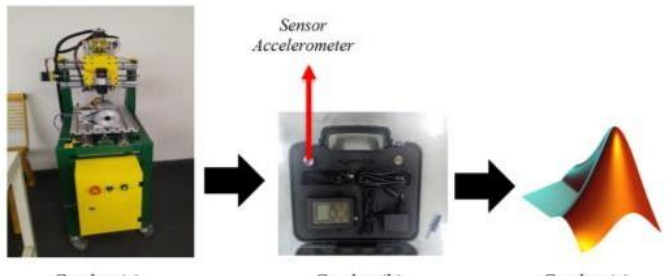

Keterangan:

Gambar (a)

Gambar (b)

Gambar (c)

(a) Mesin CNC Router 4 Axis

(b) Sensor Accelerometer

(c) Software Matlab

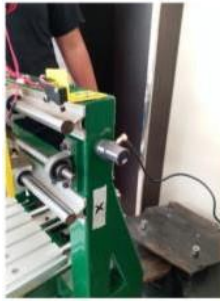

Gambar (a)

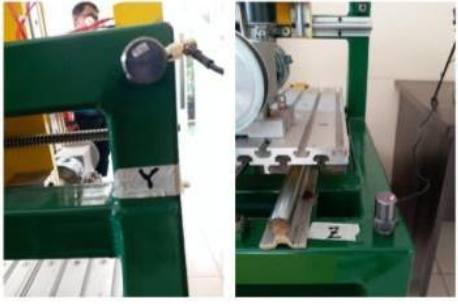

Gambar (b)

Gambar (c)

Keterangan :

(a) Pengujian Bump Test Sumbu x Kerangka Atas

(b) Pengujian Bump Test Sumbu y Kerangka Atas

(c) Pengujian Bump Test Sumbu z Kerangka Atas
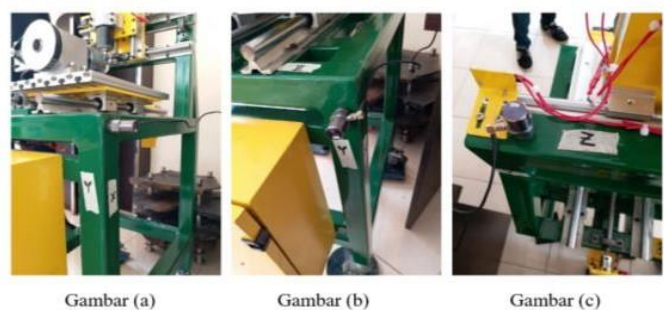

Keterangan :

Gambar (b)

Gambar (c)

(a) Pengujian Bump Test Sumbu x Kerangka Bawah

(b) Pengujian Bump Test Sumbu y Kerangka Bawah

(c) Pengujian Bump Test Sumbu z Kerangka Bawah

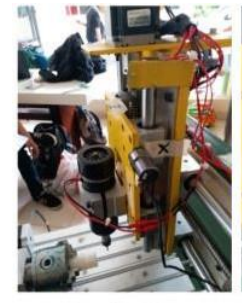

Gambar (a)

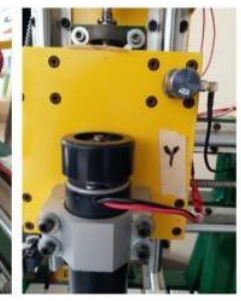

Gambar (b)

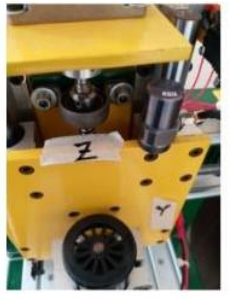

Gambar (c)

Keterangan:
(a) Pengujian Bump Test Sumbu x Spindle
(b) Pengujian Bump Test Sumbu y Spindle
(c) Pengujian Bump Test Sumbu z Spindle 


\section{HASIL DAN PEMBAHASAN}

Hasil eksperimen pada kerangka atas dalam kondisi mesin normal dapat dilihat pada gambar dibawah ini :
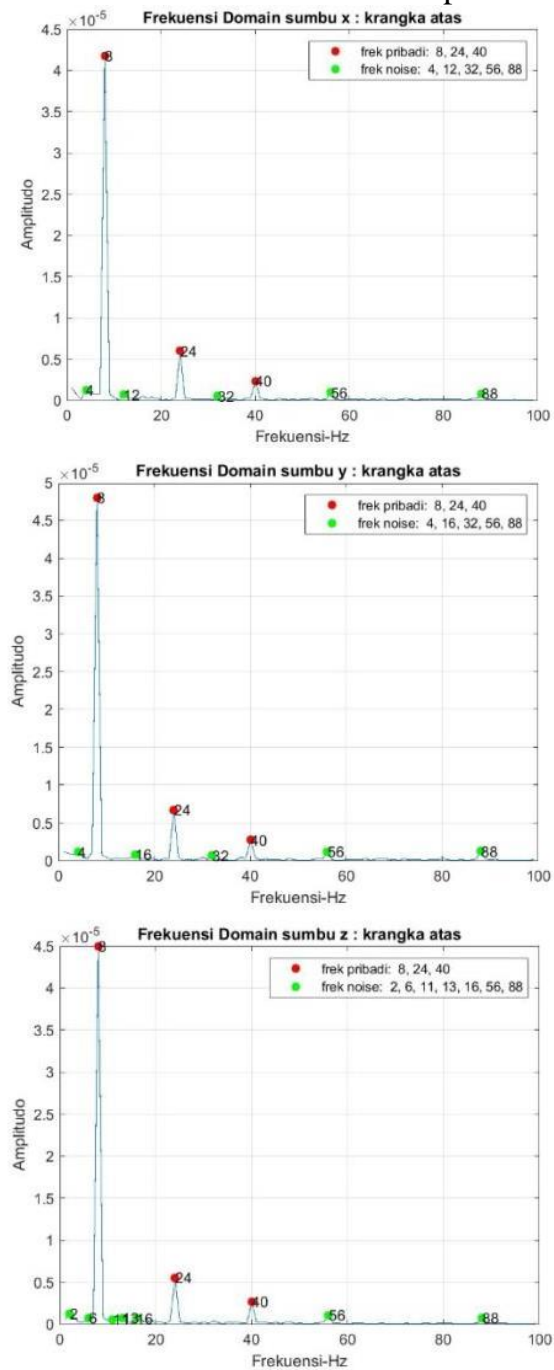

Gambar 3. Hasil Eksperimen pada Kerangka Atas - Normal 
SISTEMIK(Jurnal Ilmiah Nasional Bidang Ilmu Teknik)

Vol. 09 No. 02 Desember 2021

P-ISSN : 2337-3636 || E-ISSN : 2527-6425

Hasil eksperimen pada kerangka bawah dalam kondisi mesin normal dapat dilihat pada gambar dibawah ini :
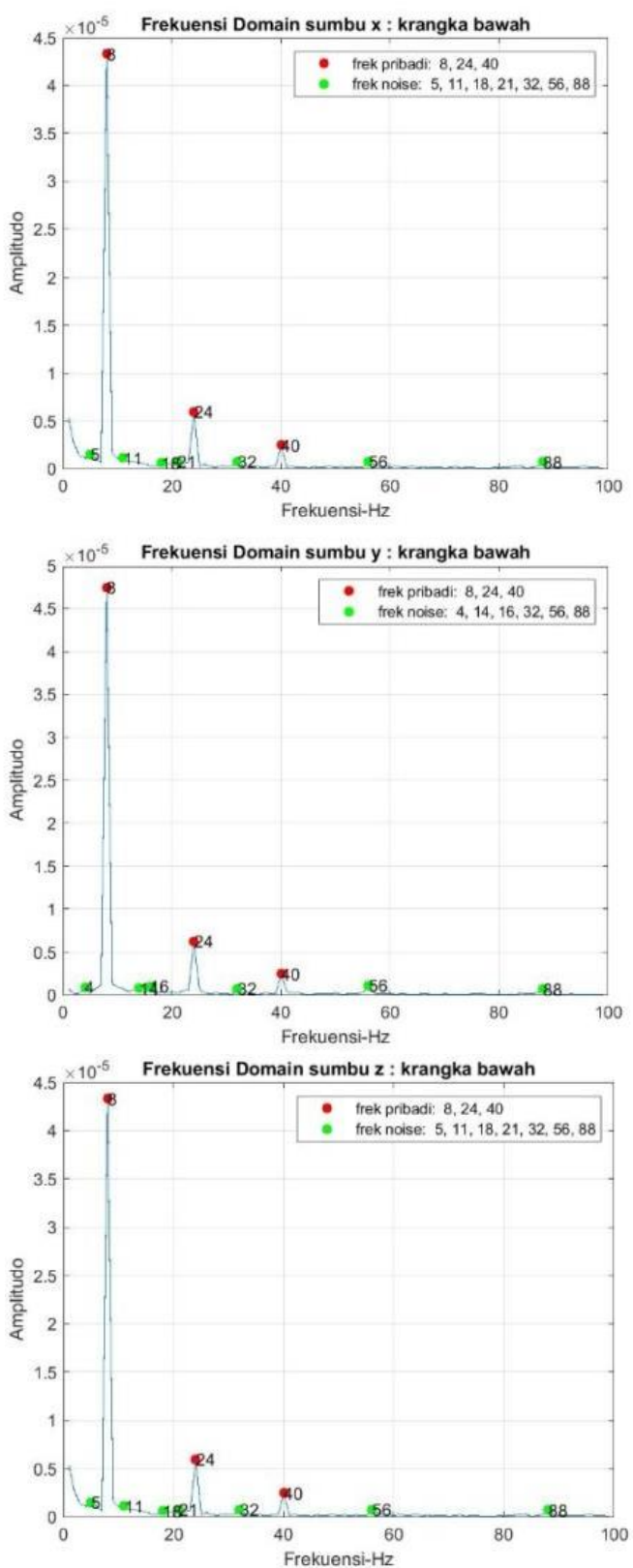

Gambar 4. Hasil Eksperimen pada Kerangka Bawah-Normal 
Hasil eksperimen pada spindle dalam kondisi mesin normal dapat dilihat pada gambar dibawah ini :
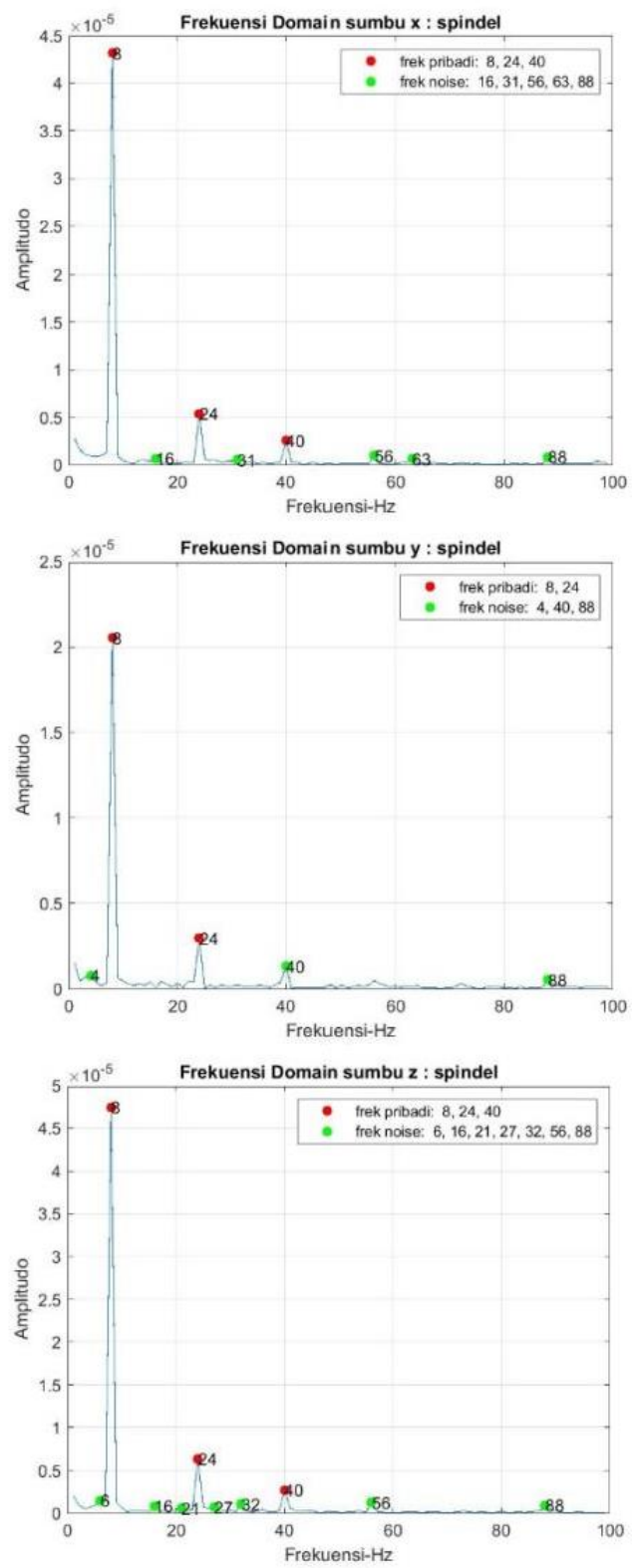

Gambar 5. Hasil Eksperimen pada Spindle-Normal

Pada plot diatas, hampir semuanya didapatkan frekuensi pribadi yang dominan yaitu 8, 24, dan $40 \mathrm{~Hz}$ yang dapat dilihat pada tabel dibawah :

TABEL I

FREKUENSI PRIBADI - NORMAL

\begin{tabular}{|c|c|c|c|c|c|c|c|c|c|}
\hline \multirow{2}{*}{ No } & \multicolumn{8}{|c|}{ Krekuensi Pribadi Mesin CNC Normal } \\
\cline { 2 - 10 } & \multicolumn{3}{|c|}{ Kerangka Atas } & \multicolumn{3}{|c|}{ Kerangka Bawah } & \multicolumn{3}{|c|}{ Spindel } \\
\cline { 2 - 10 } & $\boldsymbol{x}$ & $\boldsymbol{y}$ & $\boldsymbol{z}$ & $\boldsymbol{x}$ & $\boldsymbol{y}$ & $\boldsymbol{z}$ & $\boldsymbol{x}$ & $\boldsymbol{y}$ & $\boldsymbol{z}$ \\
\hline 1 & 8 & 8 & 8 & 8 & 8 & 8 & 8 & 8 & 8 \\
\hline 2 & 24 & 24 & 24 & 24 & 24 & 24 & 24 & 24 & 24 \\
\hline 3 & 40 & 40 & 40 & 40 & 40 & 40 & 40 & - & 40 \\
\hline
\end{tabular}


SISTEMIK(Jurnal Ilmiah Nasional Bidang Ilmu Teknik)

Vol. 09 No. 02 Desember 2021

P-ISSN : 2337-3636 || E-ISSN : 2527-6425

Hasil eksperimen pada kerangka atas dalam kondisi mesin rusak dapat dilihat pada gambar dibawah ini :
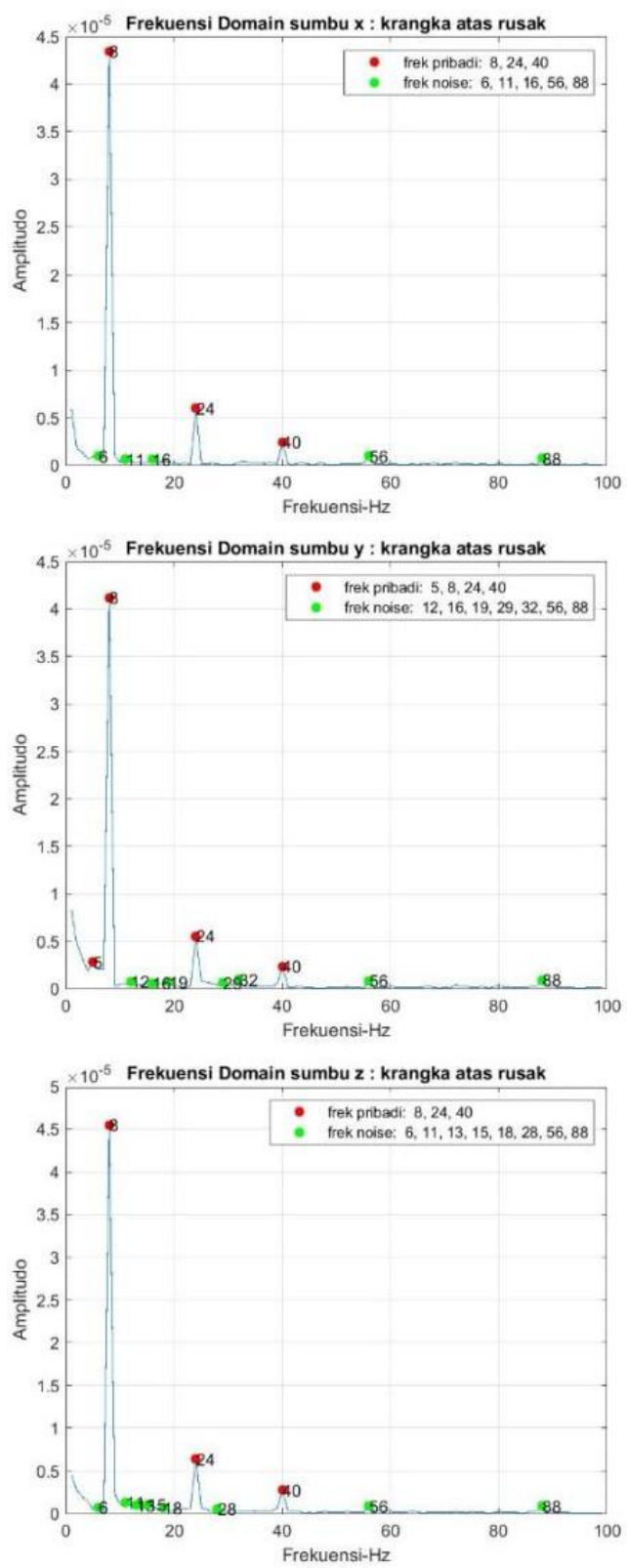

Gambar 6. Hasil Eksperimen pada Kerangka Atas - Rusak 
Hasil eksperimen pada spindle dalam kondisi mesin rusak dapat dilihat pada gambar dibawah ini :
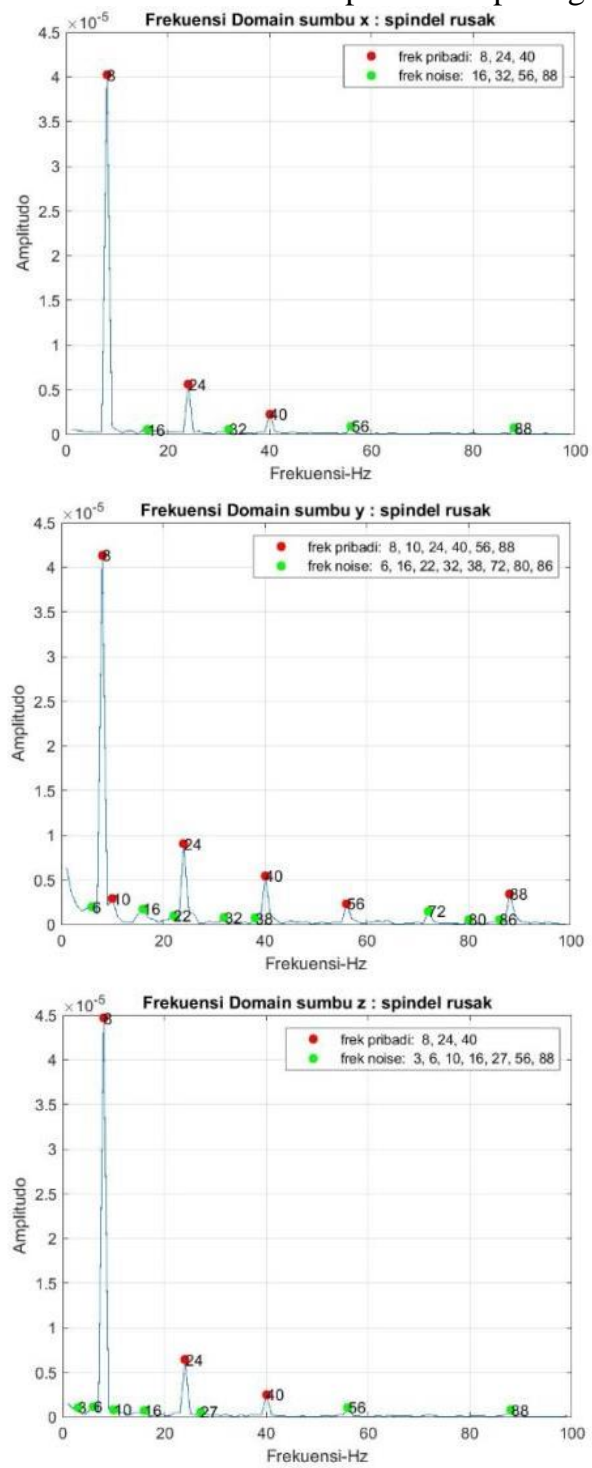

Gambar 8. Hasil Eksperimen pada Spindle-Rusak

Pada plot diatas, hampir semuanya didapatkan frekuensi pribadi yang dominan yaitu 8, 24, dan $40 \mathrm{~Hz}$ akan tetapi Terdapat pergeseran frekuensi yang mengakibatkan getaran berlebih pada "Sumbu y Kerangka Atas" dan "Sumbu y Spindle". yang dapat dilihat pada tabel dibawah :

TABEL II

TABEL ISIAN UNTUK FREKUENSI PRIBADI - RUSAK

\begin{tabular}{|c|c|c|c|c|c|c|c|c|c|}
\hline \multirow{2}{*}{ No } & \multicolumn{8}{|c|}{ Frekuensi Pribadi Mesin CNC Rusak } \\
\cline { 2 - 11 } & \multicolumn{2}{|c|}{ Kerangka Atas } & \multicolumn{3}{|c|}{ Kerangka Bawah } & \multicolumn{3}{|c|}{ Spindel } \\
\hline & $\boldsymbol{x}$ & $\boldsymbol{y}$ & $\boldsymbol{z}$ & $\boldsymbol{x}$ & $\boldsymbol{y}$ & $\boldsymbol{z}$ & $\boldsymbol{x}$ & $\boldsymbol{y}$ & $\boldsymbol{z}$ \\
\hline 1 & 8 & 5 & 8 & 8 & 8 & 8 & 8 & 8 & 8 \\
\hline 2 & 24 & - & 24 & 24 & 24 & 24 & 24 & 10 & 24 \\
\hline 3 & 40 & 24 & 40 & 40 & 40 & 40 & 40 & 24 & 40 \\
\hline 4 & - & 40 & - & - & - & - & - & 40 & - \\
\hline 5 & - & - & - & - & - & - & - & 56 & - \\
\hline 6 & - & - & - & - & - & - & - & 88 & - \\
\hline
\end{tabular}


Perhitungan nilai konstanta menggunakan persamaan (15) dengan hasil yang dapat dilihat pada tabel dibawah : TABEL III

TABEL NILAI KONSTANTA - NORMAL

\begin{tabular}{|c|c|c|c|c|c|c|c|c|c|}
\hline \multirow{3}{*}{ No } & \multicolumn{8}{|c|}{ Nilai Konstanta (k) Mesin CNC Kondisi Normal } \\
\cline { 2 - 10 } & \multicolumn{3}{|c|}{ Kerangka Atas } & \multicolumn{2}{c|}{ Kerangka Bawah } & \multicolumn{3}{|c|}{ Spindel } \\
\cline { 2 - 10 } & $\boldsymbol{x}$ & $\boldsymbol{y}$ & $\boldsymbol{z}$ & $\boldsymbol{x}$ & $\boldsymbol{y}$ & $\boldsymbol{z}$ & $\boldsymbol{x}$ & $\boldsymbol{y}$ & $\boldsymbol{z}$ \\
\hline 1 & 5120 & 5120 & 5120 & 5120 & 5120 & 5120 & 5120 & 5120 & 5120 \\
\hline 2 & 46080 & 46080 & 46080 & 46080 & 46080 & 46080 & 46080 & 46080 & 46080 \\
\hline 3 & 128000 & 128000 & 128000 & 128000 & 128000 & 128000 & 128000 & - & 128000 \\
\hline
\end{tabular}

TABEL IV

TABEL NILAI KONSTANTA - RUSAK

\begin{tabular}{|c|c|c|c|c|c|c|c|c|c|}
\hline \multirow{3}{*}{ No } & \multicolumn{9}{|c|}{ Nilai Konstanta (k) Mesin CNC Kondisi Rusak } \\
\hline & \multicolumn{3}{|c|}{ Kerangka Atas } & \multicolumn{3}{|c|}{ Kerangka Bawah } & \multicolumn{3}{|c|}{ Spindel } \\
\hline & $x$ & $y$ & $z$ & $x$ & $y$ & $z$ & $x$ & $y$ & $z$ \\
\hline & 5120 & 2000 & 5120 & 5120 & 5120 & 5120 & 5120 & 5120 & 5120 \\
\hline & 46080 & 5120 & 46080 & 46080 & 46080 & 46080 & 46080 & 8000 & 46080 \\
\hline 3 & 128000 & 46080 & 128000 & 128000 & 128000 & 128000 & 128000 & 46080 & 128000 \\
\hline 4 & & 128000 & & & & & & 128000 & \\
\hline 5 & & & & & & & & 250880 & \\
\hline & & & & & & & & 619520 & \\
\hline
\end{tabular}

Perhitungan rasio redaman menggunakan persamaan (16) dengan hasil yang dapat dilihat pada tabel dibawah : TABEL V

TABEL NILAI RASIO REDAMAN - NORMAL

\begin{tabular}{|c|c|c|c|c|c|c|c|c|c|}
\hline \multirow{3}{*}{ No } & \multicolumn{8}{|c|}{ Nilai Rasio Redaman (q) Mesin CNC Kondisi Normal } \\
\cline { 2 - 10 } & \multicolumn{3}{|c|}{ Kerangka Atas } & \multicolumn{2}{c|}{ Kerangka Bawah } & \multicolumn{3}{|c|}{ Spindel } \\
\cline { 2 - 10 } & $\boldsymbol{x}$ & $\boldsymbol{y}$ & $\boldsymbol{z}$ & $\boldsymbol{x}$ & $\boldsymbol{y}$ & $\boldsymbol{z}$ & $\boldsymbol{x}$ & $\boldsymbol{y}$ & $\boldsymbol{z}$ \\
\hline 1 & 0,12153 & 0,12153 & 0,12153 & 0,12153 & 0,12153 & 0,12153 & 0,12153 & 0,12153 & 0,12153 \\
\hline 2 & 0.058 & 0.058 & 0.058 & 0.058 & 0.058 & 0.058 & 0.058 & 0.058 & 0.058 \\
\hline 3 & 0.035 & 0.035 & 0.035 & 0.035 & 0.035 & 0.035 & 0.035 & - & 0.035 \\
\hline
\end{tabular}

TABEL VI

TABEL NILAI RASIO REDAMAN - RUSAK

\begin{tabular}{|c|c|c|c|c|c|c|c|c|c|}
\hline \multirow{3}{*}{ No } & \multicolumn{8}{|c|}{ Nilai Rasio Redaman (q) Mesin CNC Kc ndisi Rusak } \\
\cline { 2 - 10 } & \multicolumn{2}{|c|}{ Kerangka Atas } & \multicolumn{2}{c|}{ Kerangka Bawah } & \multicolumn{3}{|c|}{ Spindel } \\
\cline { 2 - 10 } & $\boldsymbol{x}$ & $\boldsymbol{y}$ & $\boldsymbol{z}$ & $\boldsymbol{x}$ & $\boldsymbol{y}$ & $\boldsymbol{z}$ & $\boldsymbol{x}$ & $\boldsymbol{y}$ & $\boldsymbol{z}$ \\
\hline 1 & 0,12153 & 00.28 & 0,12153 & 0,12153 & 0,12153 & 0,12153 & 0,12153 & 0,12153 & 0,12153 \\
\hline 2 & 0.058 & 0,12153 & 0.058 & 0.058 & 0.058 & 0.058 & 0.058 & 00.14 & 0.058 \\
\hline 3 & 0.035 & 0.058 & 0.035 & 0.035 & 0.035 & 0.035 & 0.035 & 0.058 & 0.035 \\
\hline 4 & - & 0.035 & - & - & - & - & - & 0.035 & - \\
\hline 5 & - & - & - & - & - & - & - & 0.025 & - \\
\hline 6 & - & - & - & - & - & - & - & 0.016 & - \\
\hline
\end{tabular}

Perhitungan nilai demping menggunakan persamaan (17) dengan hasil yang dapat dilihat pada tabel dibawah :

TABEL VII

TABEL NILAI DEMPING - NORMAL

\begin{tabular}{|c|c|c|c|c|c|c|c|c|c|}
\hline \multirow{3}{*}{ No } & \multicolumn{8}{|c|}{ Nilai Demping (c) Mesin CNC Kondisi Normal } \\
\cline { 2 - 10 } & \multicolumn{3}{|c|}{ Kerangka Atas } & \multicolumn{2}{c|}{ Kerangka Bawah } & \multicolumn{3}{|c|}{ Spindel } \\
\cline { 2 - 10 } & $\boldsymbol{x}$ & $\boldsymbol{y}$ & $\boldsymbol{z}$ & $\boldsymbol{x}$ & $\boldsymbol{y}$ & $\boldsymbol{z}$ & $\boldsymbol{x}$ & $\boldsymbol{y}$ & $\boldsymbol{z}$ \\
\hline 1 & 224 & 224 & 224 & 224 & 224 & 224 & 224 & 224 & 224 \\
\hline 2 & 224 & 224 & 224 & 224 & 224 & 224 & 224 & 224 & 224 \\
\hline 3 & 224 & 224 & 224 & 224 & 224 & 224 & 224 & - & 224 \\
\hline
\end{tabular}

TABEL VIII

TABEL NILAI DEMPING - RUSAK

\begin{tabular}{|c|c|c|c|c|c|c|c|c|c|}
\hline \multirow{3}{*}{ No } & \multicolumn{8}{|c|}{ Nilai De mping (c) Mesin CNC Kondisi Rusak } \\
\cline { 2 - 10 } & \multicolumn{3}{|c|}{ Kerangka Atas } & \multicolumn{3}{|c|}{ Kerangka Bawah } & \multicolumn{3}{|c|}{ Spindel } \\
\cline { 2 - 10 } & $\boldsymbol{x}$ & $\boldsymbol{y}$ & $\boldsymbol{z}$ & $\boldsymbol{x}$ & $\boldsymbol{y}$ & $\boldsymbol{z}$ & $\boldsymbol{x}$ & $\boldsymbol{y}$ & $\boldsymbol{z}$ \\
\hline 1 & 224 & 224 & 224 & 224 & 224 & 224 & 224 & 224 & 224 \\
\hline 2 & 224 & 224 & 224 & 224 & 224 & 224 & 224 & 224 & 224 \\
\hline 3 & 224 & 224 & 224 & 224 & 224 & 224 & 224 & 224 & 224 \\
\hline 4 & - & 224 & - & - & - & - & - & 224 & - \\
\hline 5 & - & - & - & - & - & - & - & 224 & - \\
\hline 6 & - & - & - & - & - & - & - & 224 & - \\
\hline
\end{tabular}




\section{KESIMPULAN}

Berdasarkan penelitian yang sudah dilakukan, dapat diambil kesimpulan sebagai berikut :

1. Diperoleh bahwa pengujian ini menghasilkan frekuensi global dimana frequensi $8 \mathrm{~Hz}, 24 \mathrm{~Hz}$, dan $40 \mathrm{~Hz}$ muncul disetiap sumbu $\mathrm{x}$, y, dan z pada kerangka atas, kerangka bawah dan spindle. Pada mesin dengan kondisi rusak muncul frekuensi lokal pada sumbu y kerangka atas sebesar $5 \mathrm{~Hz}$. Kemudian pada sumbu y spindle muncul frekuensi lokal sebesar $10 \mathrm{~Hz}, 56 \mathrm{~Hz}$, dan $88 \mathrm{~Hz}$. Munculnya frekuensi lokal menandakan adanya kerusakan pada CNC oleh sumbu tertentu selain frequensi global.

2. Terdapat pergeseran frekuensi yang mengakibatkan getaran berlebih pada "Sumbu y Kerangka Atas" dan "Sumbu y Spindle“. Hal ini menunjukkan bahwa terdapat indikasi kerusakan pada sumbu tersebut. Setelah dilakukan pemeriksaan, terdapat baut yang terletak dikerangka atas tepatnya dibelakang Spindle mengalami pergeseran posisi yaitu kendor.

3. Preventive maintenance dilakukan dengan pengujian getaran metode Bump Test untuk mengetahui kerusakan Mesin CNC Router 4 Axis. Pengujian getaran dilakukan secara rutin.

\section{REFERENSI}

[1] Krar, S. \& Gill, A., 1990, CNC Technology and Programing. America -United States: McGraw- Hill.

[2] Subekti, S. (2018). Studying The Dynamic Characteristics To Lengthen The Operating Life For A Diesel Engine Using Frequency Response Function (FRF) Measurement. Sinergi, 22(3), 161-168.

[3] Delprete, C., Galeazzi, A., \& Pregno, F. (2010). Experimental modal analysis of an automotive powertrain. In Applied Mechanics and Materials (Vol. 24, pp. 71-76). Trans Tech Publications Ltd.

[4] Gulang, M. F., Haq, Z. D., Alpiyanto, H., \& Subekti, S. (2020). Karakteristik dinamik needle bearing pada camshaft dohc suzuki satria fu150 yang telah di modifikasi, dengan metode bump test. Teknika: Jurnal Sains dan Teknologi, 16(2), 237-243.

[5] Effendi, B. D., Subekti, A. H., \& HAMMID, A. (2019). Karakteristik dinamik disc brake daihatsu Sigra 1200 cc dengan metode bump test. Flywheel: Jurnal Teknik Mesin Untirta, 5(1), 14-19.

[6] Ghatwai, A. B., Chaitanya, S. V., \& Phadke, S. B. (2016). Frequency Response Function Measurements Of Disc And Drum Brake With Its Verification By Cae. International Research Journal Of Engineering And Technology, 3(5), 2223-2228.

[7] S. Subekti et al., "Inspecting a Bump Test in the Maintenance of a 1200-Cc Daihatsu Sigra Disc Brake," SINERGI, vol. 23, no. 3, pp. 191-198, 2019, DOI: 10.22441/sinergi. 2019. 3.003.

[8] Susanto, A., Yusuf, S. Q., Hamid, A., Wahyudi, H., \& Subekti, S. (2019). Implementation of frequency response function on tapper bearing maintenance. Sinergi, 23(2), 132-138.

[9] Ikhsan, M., \& Subekti, S. (2020). Analisis Getaran Tapered Roller Bearing Pada Turbine Propeller Sebelum dan Sesudah Pelumasan (Oli \& Grease) Dengan Metode Bump Test. Barometer, 5(2), 277-281.

[10] Pratiwi, M. A., Ikhsan, M., Octavianto, R. D., Hamid, A., \& Subekti, S. (2021). DYNAMIC CHARACTERIZATION OF BALL BEARING IN TURBINE PROPELLER USING BUMP TEST METHOD. Sinergi, 25(2), 135-140.

[11] Homaei, F., Shojaee, S., \& Amiri, G. G. (2015). Multiple-structural damage detection using measured frequency response function. Iranian Journal of Structural Engineering, 2(1), 13-18.

[12] Biantoro, A. W., Maryanto, H., Hidayanto, A. K., \& Hamid, A. (2020). The investigation of end mill feeds on CNC router machine using vibration method.

[13] Sangian, H., Rahman, D. A., Rudiwanto, R., Subekti, S., \& Hamid, A. (2020). Analisis getaran pada screw compressor akibat pen garuh putaran rotor. Rekayasa Mesin, 11(2), 267-275.

[14] Kamiel, B. P., Prastomo, N., \& Riyanta, B. (2019). Ekstraksi Parameter Statistik Domain Waktu Dan Domain Frekuensi Untuk Mendeteksi Kavitasi Pada Pompa Sentrifugal Berbasis Principal Component Analysis (Pca). Rekayasa Mesin, 10(2), 165-176.

[15] Rao s. s, 2004, Mechanical Vibration, Prentice-Hall, Englewood Cliffs, NJ, USA, 4th edition. 